\title{
Effect of corruption on firm level innovation: Evidence from Pakistan
}

\author{
Syed Muhammad Imran* • Hafeez Ur Rehman • Rana Ejaz Ali Khan
}

Department of Economics, The Islamia University of Bahawalpur, Pakistan

Received: 23 May 2019

Revised: 9 November 2019

Accepted: 15 November 2019

\begin{abstract}
Corruption is a widespread phenomenon in majority of the developing countries. However, literature evidenced both positive and negative impact of corruption in economies at macro level. At the micro level the studies rarely exist explaining this phenomenon. This paper empirically investigates the micro level impact of corruption on firms' innovation. Corruption at the firm level is measured by the "percent of firms expected to give gifts to public officials (to get things done)" as a proxy for corruption, and innovation is measured by "firms that introduce new or significantly improved products or services over the last three years". The results explain that corruption augments firms' innovation, that is, "grease the wheels" exists in the case of Pakistan.
\end{abstract}

Keywords: corruption; innovation; firm performance

JEL Classification Codes: D73, O31, L25

\section{Introduction}

It is well acknowledged that innovation is key driving force of economic development (Kogan et al., 2017). The process of innovation represents the dynamic and systematic advancement of products, processes and organizational work methods. It is the process of change or the transformation of knowledge, ideas, and inventions into commercially viable goods, services or processes. Overall, innovation is a driver of firm performance and economic growth. Firms engage in innovation in order to increase their productivity, competitiveness, and market share which ultimately increases their profits (Love and Roper, 2015).Though much effort has been devoted to exploring factors determining innovation, but the impact of corruption is rarely studied. In particular, corruption has been shown to significantly affect economic growth, but relatively less is known about how it affects a firm's innovation. Given the prevalence of corruption and the importance of innovation in a firm's long-term growth, this paper, examines the impact of corruption on a firm's innovation. Pakistan is one of the developing countries

\footnotetext{
*Corresponding author. E-mail: syedimran.ravian@gmail.com.

Citation: Imran, S. M., Rehman, H. U, and Khan, R. E. A. (2020) Effect of corruption on firm level innovation: Evidence from Pakistan, Economics and Business Letters, 9(1), 41-47.
}

DOI: $10.17811 /$ ebl.9.1.2020.41-47 
where corruption is comparatively more prevalent. According to the Corruption Perception Index (CPI) report by the Transparency International, Pakistan ranked at 117 with a score of 33 in 2018, while Pakistan is the 4th most corrupt country in SAARC nations. Researchers and policymakers are much concerned to investigate the effects of corruption on the economy. Hence, what are the consequences of corruption at the firm level is primarily an empirical question.

Macroeconomic studies provide aggregate measures which cannot disclose within-country variation in corruption and innovation (Fisman and Svensson, 2007). The firm-level studies regarding the impact of corruption on innovation are comparatively rare. It may be due to nonavailability of the firm-level data. A major breakthrough in the literature has been taken place when the World Bank started providing firm-level data in enterprise surveys. Cross-country evidences exist showing that corruption impedes innovation and entrepreneurship in emerging countries (Paunov, 2016). Similarly, progressively degenerate nations will in general have weak organizations that are probably going to deteriorate firms' innovation (Hirshleifer et al. 2013; Jain, 2001). However, there is large heterogeneity in the nature of institutions in the nations. So, we focus on a single country to identify the real effect of corruption on innovation. However, regardless of enormous firm-level studies on this aspect, to the best of our knowledge, none of the studies has investigated this issue for Pakistan. So, the attempt to empirically test the hypothesis that corruption "grease the wheel" or "sand the wheel" using World Enterprise database will add to literature.

Earlier studies have identified several determinants of corporate innovation productivity, such as credit market requirements (Acharya et al., 2013; Benfratello et al., 2008), financial constraint (Brown et al., 2013) and institutional investors (Aghion et al., 2013). However, only a few studies explored the effects of institutional features on firm innovation, such as bankruptcy and labor laws (Acharya et al., 2013) financial development (Ayyagari et al., 2014) and political uncertainty (Bhattacharya et al., 2017; Cumming et al., 2016). Only few studies have analyzed the effect of corruption on business policies and outcomes. For example, Beck et al. (2005) and Fisman and Svensson (2007) discovered that corruption constrains company growth. We add to this literature by considering another institutional feature, that is, corruption, as an important factor in the innovation-generating process. Secondly, the paper contributes to this body of literature about the impact of corruption at the firm level. Since innovation is essential to economic development, our research sheds more light onto the way corruption affects economic development.

\section{Review of literature}

The empirical research on corruption provides heterogeneous evidence at national and firmlevel tracks. Researchers at one strand support the hypothesis of "sand the wheels" while, other strand support "grease the wheels" hypothesis.

One strand argued that corruption is negatively linked with economic growth (Aidt, 2009; Méon and Sekkat, 2005; Ugur and Dasgupta, 2011; Zelekha and Sharabi, 2012). Firm-level studies concluded that corruption reduces innovation (Shleifer and Vishny, 1993). Anokhin and Schulze (2009) found that corrupt firms are less likely to innovate. Using cross-section data of 2000 Indian firms de Waldemar (2012) found an inverse relationship between bribe payment and product innovation, providing evidence for a sanding hypothesis. Farooq et al. (2013) examined that how corruption affects economic growth in Pakistan by augmenting trade openness and financial development. The structural break cointegration results indicated that corruption is detrimental to economic growth. Athanasouli and Goujard (2015) concluded that probability of corruption is greater for firms which are more contract dependent, having lower management practices and productivity. 
At the other strand, Méon and Weill (2010) examining the interaction between governance, corruption, and aggregate efficiency and using a panel dataset of 69 developed and developing countries found that countries with extremely ineffective institutions provide support for greasing hypothesis. Dreher and Gassebner (2013) found positive relationship between corruption and the number of new entrepreneurs. Goedhuys et al. (2016) using the dataset of World Bank Enterprise Survey of 3489 firms in Egypt and Tunisia analyzed the direct and indirect effect of corruption on innovation and firm growth. They used four types of innovation measures (product, process, organizational, and marketing) but mainly focused on product innovation. The results revealed that the severity of bureaucratic and institutional obstacles increase the likelihood to innovate. Nguyen et al. (2016) used a Logit model on SMEs data of 2500 Vietnam firms to investigate the impact of petty corruption on innovation and concluded that corruption is good for innovation. Huang (2016) investigated the impact of corruption on growth for a panel of Asia Pacific countries using bootstrap panel Granger causality approach. The study concluded that corruption is not bad for growth in Asia-Pacific region. Imran et al. (2019) analyzed the impact of corruption on firm performance in disaggregated and aggregated data set of 147 economies. They concluded that corruption augments firm performance in lower income nation and reduces firm performance in middle and upper income economies. The current study departs from the previous literature in the way that, it is focusing on Pakistan economy by using World Bank Enterprise Survey.

\section{Methodology}

To test the impact of corruption on firms' innovation we consider core and control variables to construct a framework. The core variable includes corruption, while control variables mainly cover firm-specific characteristics. Therefore, the probability of firm innovation in logit specification is shown as follows:

$$
L_{i}=\operatorname{Ln}\left(\frac{P_{i}}{1-P_{i}}\right)=\Omega_{0}+\Omega_{1} \operatorname{COR}_{i}+\Omega_{2} X_{i}+u_{i}
$$

where, $P_{i}=1$ is probability of innovation and $P_{i}=0$ is that of no innovation. COR is a variable of interest and $X_{i}$ is the vector of control variables that includes exports, external audit, skilled workers, manager experience and firm-specific characteristics such as registration and ownership of firm, firm age, and size. We write the above model as:

$$
\begin{gathered}
\operatorname{Pr}\left(\text { INNOVATION }_{\mathrm{i}}=1\right)=\Omega_{0}+\Omega_{1} \text { COR }_{\mathrm{i}}+\Omega_{2} \text { DOMFIR }_{\mathrm{i}}+\Omega_{3} \text { REGFIR }_{\mathrm{i}}+ \\
\Omega_{4} \text { FAGE }_{\mathrm{i}}+\Omega_{5} \text { FSIZE }_{\mathrm{i}}+\Omega_{6} \text { MANEXP }_{\mathrm{i}}+\Omega_{7} \text { EXAUDIT }_{\mathrm{i}}+\Omega_{8} \text { SWOR }_{\mathrm{i}}+\Omega_{9} \text { EXP }_{\mathrm{i}}+\varepsilon_{\mathrm{i}}
\end{gathered}
$$

where INNOVATION $i$ is dummy variable, measured by "firms that introduce new or significantly improved products or services over the last three years". Literature regarding the impact of corruption on firm performance provide heterogeneous evidence. Corruption work as "grease the wheel" (Jiang and Nie, 2014; Mendoza et al., 2015; Sequeira and Djankov, 2014; Veracierto, 2008; Vial and Hanoteau, 2010) as well as "sand the wheel" (Anokhin and Schulze, 2009; Asiedu and Freeman, 2009; Fisman and Svensson, 2007). For Pakistan, it is speculated that corruption has negative impact on innovation. COR is corruption measured by "percent of firms expected to give gifts to public officials (to get things done)". Diaby and Sylwester (2014) consider this measure as a proxy for petty corruption ${ }^{1}$. We use a more inclusive approach to quantify the relationship between corruption and innovation because introducing new products are associated with greater bribe payments to public officials (Ayyagari et al., 2010). DOMFIR is the ownership of the firm measured by "percentage of firms that have at least $10 \%$ owned by domestic individuals, companies, or organizations". REGFIR is firm registration measured by

\footnotetext{
${ }^{1}$ Transparency International (2017) classified corruption into three groups as i.) petty, ii.) grand, iii.) political.
} 
"was this establishment formally registered when it began operations". FAGE is firm age measured by "in what year did this establishment began operations". It is speculated that age of the firm increases the likelihood of firm innovation (Č́aelková and Hanousek, 2004; Kuncoro, 2004). FSIZE is the firm size measured by "the number of permanent workers" (small= worker $>5$ and $<20$; medium $=$ worker $>20$ and $<99$; large $=$ worker $>100$ ). We have combined the medium and small firms to make it binary for utilizing dummy variables. The small firms are assumed as 0, otherwise 1. Same type of transformation was adopted by Lee and Oh (2010). MANEXP is manger experience in years. It is speculated that experience of manager improves firm's innovation (Collins et al., 2009). EXAUDIT is external audit measured by "percentage of firms with their annual financial statement reviewed by an external auditor" (Safavian et al., 2001). It is speculated that external audit increase likelihood of innovation. SWOR is skilled workers measured by "proportion of skilled workers out of all production workers". EXP is export measured by "proportion of total sales that are exported directly". It is speculated that exports of the firm increase likelihood of firm innovation.

\section{Data contribution}

This paper utilized enterprise survey data of 1247 Pakistani firms taken from World Bank (2013). There were a number of missing values like 447 for corruption, 36 for domestic firms, 79 for registered firms, 120 for firm age, 462 for firm size, 70 for manager experience, 116 for external audit, 206 for skilled workers, and 99 for exports. Finally, we regress the model with 659 observation.

Table 1 Impact of corruption on firm Innovation

\begin{tabular}{lrrrr}
\hline \hline DV: Innovation & Coefficient & Standard Errors & Z Statistics & Probability \\
\hline Corruption & $1.14852^{*}$ & 0.29610 & 3.88 & 0.000 \\
Domestic Firms & 0.01181 & 0.01232 & 0.96 & 0.338 \\
Registered Firms & $1.94163^{*}$ & 0.51567 & 3.77 & 0.000 \\
Firm Age & $0.02857^{*}$ & 0.01151 & 2.48 & 0.013 \\
Firm Size & -0.30825 & 0.36542 & -0.84 & 0.399 \\
Manager Experience & $0.98054^{*}$ & 0.45412 & 2.16 & 0.031 \\
External Audit & 0.00579 & 0.00747 & 0.78 & 0.438 \\
Skilled Workers & $1.14233^{*}$ & 0.30611 & 3.73 & 0.000 \\
Exports & $0.01378^{*}$ & 0.00631 & 2.18 & 0.029 \\
Constant & -3.42706 & 1.35498 & -2.53 & 0.011 \\
\hline Observation & 659 & & & \\
Pseudo R-squared & 0.0762 & & & \\
Wald chi square & 60.17 & & & \\
Prob & 0.000 & & & \\
\hline \hline
\end{tabular}

Note. ${ }^{*}$ denotes significant at $5 \%$. standard errors are robust.

\section{Results}

Our results show that corruption and innovation are positively and significantly associated. Therefore, we find evidence of "grease the wheels". Pakistan is a highly corrupt nation and firms take advantage of this poor institutional quality by giving bribes to a public official to speed up lengthy procedures. Our results are in line with the findings of Krammer (2013) and Méon and Weill (2010) for transition economies and developed and developing nations respectively. The justification for positive relationship is that firm consider corruption as a second-best solution to innovate and in the short run, it acts as transaction cost which increases the certainty in decision making. The results show that registered firms are more likely to innovate. Older firms have greater probability for innovation. They have experience which 
increase the likelihood of innovation (Čábelková and Hanousek, 2004; Kuncoro, 2004). The effect of manager experience on innovation is positive which indicate that higher the manager experience greater the innovation of the firm. The result of skilled worker shows positive and significant association with innovation. The skilled workers are highly educated, formally trained and more equipped with human capital, so they attempt to increase firm profitability through innovation. The effect of exports on innovation shows positive association which indicate that export-oriented firms are more likely to innovate.

\section{Conclusion}

This paper empirically tests the hypothesis that whether corruption works as "grease the wheels" or "sand the wheels" for firm innovation. The results of the Logit model show that corruption increase the likelihood of innovation in Pakistan. Therefore, the evidence supports the "grease the wheels" hypothesis in the case of Pakistan. The benefits that firms obtained (with regard to customs, taxes, licenses, regulation, and services) through paying bribes to public official are either temporary and increase firm innovation only in the short run. Therefore, we do not encourage corrupt practices but given the weak institutional structure of the economy, we suggest that policymakers should take these firms' advantages into account while fighting corruption. The government should take measures to reduce procedural hurdles in getting new licenses and permits and reward those firm who are honest and resist corrupt practices. In this regard the demand side and supply side measures should be taken. Firms' willingness to pay bribes to a public official to get things done is due to the result of only supplyside anti-corruption policies. Demand side anti-corruption measures should be taken as per law to reduce firm willingness to offer bribes. The individual, communities, and the government, all should play their role to reduce corruption. As the result indicates that registered firms are more innovative. So, government should simplify the registration procedure. Government should also spend more on education sector to increase the training and skill of the workers. As export-oriented firms are more innovative, government should also formulate policies for export promotion of the firms.

\section{References:}

Acharya, V. V., Baghai, R. P., and Subramanian, K. V. (2013a) Labor laws and innovation, Journal of Law and Economics, 56(4), 997-1037.

Acharya, V. V., Baghai, R. P., and Subramanian, K. V. (2013b) Wrongful discharge laws and innovation, Review of Financial Studies, 27(1), 301-346.

Aghion, P., Van Reenen, J., and Zingales, L. (2013) Innovation and institutional ownership, American Economic Review, 103(1), 277-304.

Aidt, T. S. (2009) Corruption, institutions, and economic development, Oxford Review of Economic Policy, 25(2), 271-291.

Anokhin, S., and Schulze, W. S. (2009) Entrepreneurship, innovation, and corruption, Journal of Business Venturing, 24(5), 465-476.

Asiedu, E., and Freeman, J. (2009) The effect of corruption on investment growth: Evidence from firms in Latin America, Sub-Saharan Africa, and transition countries, Review of Development Economics, 13(2), 200-214.

Athanasouli, D., and Goujard, A. (2015) Corruption and management practices: Firm level evidence. Journal of Comparative Economics, 43(4), 1014-1034.

Ayyagari, M., Demirgüç-Kunt, A., and Maksimovic, V. (2010) Are innovating firms victims or perpetrators? Tax evasion, bribe payments, and the role of external finance in developing countries, The World Bank Development Research Group Working Papers, No. 5389. 
Ayyagari, M., Demirgüç-Kunt, A., and Maksimovic, V. (2014) Bribe payments and innovation in developing countries: Are innovating firms disproportionately affected?, Journal of Financial and Quantitative Analysis, 49(1), 51-75.

Beck, T., Demirgüç-Kunt, A., and Maksimovic, V. (2005) Financial and Legal Constraints to Growth: Does Firm Size Matter?, Journal of Finance, 60(1), 137-177.

Benfratello, L., Schiantarelli, F., and Sembenelli, A. (2008) Banks and innovation: Microeconometric evidence on Italian firms, Journal of Financial Economics, 90(2), 197217.

Bhattacharya, U., Hsu, P.-H., Tian, X., and Xu, Y. (2017) What affects innovation more: Policy or policy uncertainty?, Journal of Financial and Quantitative Analysis, 52(5), 1869-1901.

Brown, J. R., Martinsson, G., and Petersen, B. C. (2013) Law, stock markets, and innovation, Journal of Finance, 68(4), 1517-1549.

Čábelková, I., and Hanousek, J. (2004) The power of negative thinking: corruption, perception and willingness to bribe in Ukraine, Applied Economics, 36(4), 383-397.

Collins, J. D., Uhlenbruck, K., and Rodriguez, P. (2009) Why Firms Engage in Corruption: A Top Management Perspective, Journal of Business Ethics, 87(1), 89-108.

Cumming, D., Rui, O., and Wu, Y. (2016) Political instability, access to private debt, and innovation investment in China, Emerging Markets Review, 29, 68-81.

de Waldemar, F. S. (2012) New products and corruption: evidence from Indian firms, Developing Economies, 50(3), 268-284.

Diaby, A., and Sylwester, K. (2014) Bureaucratic competition and public corruption: Evidence from transition countries, European Journal of Political Economy, 35, 75-87.

Dreher, A., and Gassebner, M. (2013) Greasing the wheels? The impact of regulations and corruption on firm entry, Public Choice, 155(3), 413-432.

Farooq, A., Shahbaz, M., Arouri, M., \& Teulon, F. (2013) Does corruption impede economic growth in Pakistan?, Economic Modelling, 35, 622-633.

Fisman, R., and Svensson, J. (2007) Are corruption and taxation really harmful to growth? Firm level evidence, Journal of Development Economics, 83(1), 63-75.

Goedhuys, M., Mohnen, P., and Taha, T. (2016) Corruption, innovation and firm growth: firmlevel evidence from Egypt and Tunisia, Eurasian Business Review, 6(3), 299-322.

Hirshleifer, D., Hsu, P.-H., and Li, D. (2013) Innovative efficiency and stock returns, Journal of Financial Economics, 107(3), 632-654.

Huang, C.J. (2016) Is corruption bad for economic growth? Evidence from Asia-Pacific countries, North American Journal of Economics and Finance, 35, 247-256.

Imran, S.M., Rehman, H., and Khan, R.E.A. (2019) Determinants of corruption and its impact on firm performance: Global Evidence, Pakistan Journal of Commerce and Social Sciences, 13 (4), 1017-1028.

Jain, A. K. (2001) Corruption: A Review, Journal of Economic Surveys, 15(1), 71-121.

Jiang, T., and Nie, H. (2014) The stained China miracle: Corruption, regulation, and firm performance, Economics Letters, 123(3), 366-369.

Kogan, L., Papanikolaou, D., Seru, A., and Stoffman, N. (2017) Technological Innovation, Resource Allocation, and Growth, Quarterly Journal of Economics, 132(2), 665-712.

Krammer, S. M. S. (2013) Greasing the wheels of change: The impact of corruption on firms innovation in transition economies, Proceedings of the 35th DRUID Celebration Conference, 17-19.

Kuncoro, A. (2004) Bribery in Indonesia: some evidence from micro-level data, Bulletin of Indonesian Economic Studies, 40(3), 329-354.

Lee, S. H., and Oh, K. E. (2010) Why do firms bribe? Insights from residual control theory into firms' exposure and vulnerability to, Management International Review, 50(6), 775-796.

Love, J. H., and Roper, S. (2015) SME innovation, exporting and growth: A review of existing 
evidence, International Small Business Journal, 33(1), 28-48.

Mendoza, R. U., Lim, R. A., and Lopez, A. O. (2015) Grease or Sand in the Wheels of Commerce? Firm Level Evidence on Corruption and SMES, Journal of International Development, 27(4), 415-439.

Méon, P.-G., and Sekkat, K. (2005) Does corruption grease or sand the wheels of growth?, Public Choice, 122(1), 69-97.

Méon, P.-G., and Weill, L. (2010) Is corruption an efficient grease?, World Development, 38(3), 244-259.

Nguyen, N. A., Doan, Q. H., Nguyen, N. M., and Tran-Nam, B. (2016) The impact of petty corruption on firm innovation in Vietnam, Crime, Law and Social Change, 65(4-5), 377394.

Paunov, C. (2016) Corruption's asymmetric impacts on firm innovation, Journal of Development Economics, 118, 216-231.

Safavian, M. S., Graham, D. H., \& Gonzalez-Vega, C. (2001) Corruption and microenterprises in Russia, World Development, 29(7), 1215-1224.

Sequeira, S., \& Djankov, S. (2014) Corruption and firm behavior: Evidence from African ports, Journal of International Economics, 94(2), 277-294.

Shleifer, A., and Vishny, R. W. (1993) Corruption, Quarterly Journal of Economics, 108(3), 599-617.

Ugur, M., and Dasgupta, N. (2011) Corruption and economic growth: A meta-analysis of the evidence on low-income countries and beyond, retrieved from https://mpra.ub.unimuenchen.de/31226/.

Veracierto, M. (2008) Corruption and innovation, Economic Perspectives, 32(1).

Vial, V., and Hanoteau, J. (2010) Corruption, Manufacturing Plant Growth, and the Asian Paradox: Indonesian Evidence, World Development, 38(5), 693-705.

Zelekha, Y., and Sharabi, E. (2012) Corruption, institutions and trade, Economics of Governance, 13(2), 169-192. 